\title{
Surface morphology changes of acrylic resins during finishing and polishing phases
}

\author{
Glaucio Serra², Liliane Siqueira de Morais², Carlos Nelson Elias ${ }^{3}$
}

Introduction: The finishing and polishing phases are essential to improve smoothness and shining on the surface of acrylic resins used to make removable orthodontic appliances. A good surface finishing reduces roughness, which facilitates hygiene, prevents staining and provides greater comfort to the patients. Objective: The aim of this paper was to analyze the changes on surface morphology of acrylic resins during finishing and polishing phases.Methods: Thirty discs $(10 \mathrm{~mm}$ in diameter and $5 \mathrm{~mm}$ in length) were made with acrylic resin and randomly divided into ten groups. The control group did not receive any treatment while the other groups received gradual finishing and polishing. The last group received the entire finishing and polishing procedures. Surface morphology was qualitatively analyzed through scanning electron microscopy and quantitatively analyzed through a laser profilometer test. Results: The acrylic resin surfaces without treatment showed bubbles which were not observed in the subsequent phases. Wearing out with multilaminated burs, finishing with wood sandpaper and finishing with water sandpaper resulted in surfaces with decreasing irregularities. The surfaces that were polished with pumice and with low abrasive liquids showed high superficial smoothness. Conclusion: Highly smooth acrylic resin surfaces can be obtained after mechanical finishing and polishing performed with multilaminated burs, wood sandpaper, water sandpaper, pumice and low abrasive liquids.

Keywords: Acrylic resins. Scanning electron microscopy. Surface properties.

Introdução: as etapas de acabamento e polimento são essenciais para a obtenção de lisura e brilho da superfície de resinas acrílicas utilizadas na confecção de aparelhos ortodônticos. O bom acabamento da resina facilita a higiene, previne o manchamento e propicia maior conforto ao paciente. Objetivo: o objetivo desse trabalho foi analisar as alterações na morfologia superficial de resinas acrílicas (Clássico, São Paulo) durante as etapas do acabamento e polimento mecânico. Métodos: foram confeccionados 30 discos $(10 \mathrm{~mm}$ de diâmetro e $5 \mathrm{~mm}$ de altura) de resina acrílica autopolimerizável, que foram divididos aleatoriamente em dez grupos. O grupo controle não recebeu nenhum tratamento. Os demais grupos receberam acabamento e polimento graduais. O último grupo recebeu todo o tratamento de acabamento e polimento. A morfologia superficial foi avaliada qualitativamente por microscopia eletrônica de varredura e quantitativamente pela análise da rugosidade superficial. Resultados: as superfícies de resina acrílica sem tratamento apresentaram bolhas, as quais não foram observadas nas fases subsequentes. $\mathrm{O}$ desgaste com fresa multilaminada seguido de acabamento com lixa de madeira e lixa d'água produziram superfícies com irregularidades decrescentes. As superfícies polidas com branco de Espanha e líquido de baixa abrasividade (Kaol) apresentaram bom acabamento superficial. Conclusão: é possível obter resina acrílica com alta lisura superficial após acabamento e polimento mecânico com fresas, lixas de madeira, lixas d'água, branco de Espanha e líquidos de baixa abrasividade (Kaol).

Palavras-chave: Resinas acrílicas. Microscopia eletrônica de varredura. Propriedades de superfície.

\footnotetext{
${ }^{1}$ Adjunct professor, Fluminense Federal University.

${ }^{2}$ Professor of Orthodontics, Gama Filho University.

${ }^{3}$ Adjunct professor, Military Institute of Engineering (IME)

" The authors report no commercial, proprietary or financial interest in the products or companies described in this article.
}

How to cite this article: Serra G, Morais LS, Elias CN. Surface morphology changes of acrylic resins during finishing and polishing phases. Dental Press J Orthod. 2013 Nov-Dec;18(6):26-30.

Submitted: August 09, 2010 - Revised and accepted: December 21, 2010

Contact address: Glaucio Serra Guimarães

Av. Nossa Senhora de Copacabana, 647, 1108 - Copacabana/RJ - Brazil

CEP: 22050-901 - E-mail: gserrag@hotmail.com 


\section{INTRODUCTION}

Orthodontic appliances are used on upper and lower dental arches with the purpose of preventing, intercepting, correcting or retaining orthodontic issues. ${ }^{6,11}$ A wide variety of appliances are proposed, either fixed or removable, in accordance with the main purpose of the treatment. As examples we can mention: expansion appliances to correct crossbites, ${ }^{6,4}$ facial masks to correct maxillary retrognatism, ${ }^{3}$ removable appliances with Hawley clasp for retaining, ${ }^{18}$ space retrievers and space maintainers, fixed inclined plane to correct dental crossbite, ${ }^{9}$ among others.

The first step towards making a removable orthodontic appliance is the molding and production of working casts, on which the retention claps are made. The working casts are isolated with vaseline and acrylization takes place. Self-curing acrylic resin is applied to the casts by means of the Nealon technique (powder and liquid) with thickness greater than the desired, enabling finishing and polishing procedures to take place by means of wearing out procedures. ${ }^{9}$

A wide variety of finishing and polishing techniques have been proposed, ${ }^{2,13}$ either by conventional mechanical procedures or by chemical procedures which consist in immersion in a monomer-based polishing liquid.

Chemically polishing acrylic resins produces a smooth and shiny surface. ${ }^{8}$ However, it reduces mechanical resistance when compared with mechanical polishing, since it adversely affects resin resistance and structure, increasing the chances of deformation. ${ }^{11}$

In mechanical polishing, multilaminated burs are used to remove excess acrylic, to give shape and to smooth the surface. Finishing starts with 150, 180, and 220 wood sandpaper, free of water, with the purpose of obtaining a surface as flat as possible. Afterwards, 400, 600, and 1200 water sandpaper, under a small flood of water, is used until a uniform surface can be seen, without the marks left by wood sandpaper. Polishing is performed with a cotton wheel and a mix of pumice and water. This phase is accomplished when a flat, polished, and shiny surface is seen, without the marks left by water sandpaper. To eliminate the pumice, the appliance is cleaned and dried. The final polishing of the appliance is performed with a woolen wheel and low abrasive liquids for metal polishing (Brasso or Kaol). The appliance is cleaned with soap and water, and dried with paper. ${ }^{9}$
Polishing is important to facilitate the hygiene of the appliance, to hinder the incorporation of pigments or other substances originating from oral fluids, ${ }^{9}$ and to improve appliance esthetics and longevity. Furthermore, surface smoothness provides comfort to the patient who is wearing the appliance. Inappropriate finishing and polishing, polymeric surface and physicochemical properties of the material can influence plaque retention and staining, favoring the onset of periodontal diseases and cavities. ${ }^{13,15}$

Radford et $\mathrm{al}^{12}$ assessed adhesion of fungus in rough acrylic resins and found higher adhesion in rough surfaces than in smooth surfaces. There is a correlation between the number of fungus per unit of area and the wettability, in other words, the more hydrophobic the surface is, the less cellular adhesion it will have. Surfaces that promote the development of dental plaque should be worked out at the laboratory to produce polished surfaces. This will reduce bacterial adhesion and colonization.

Materials used to make removable orthodontic appliances have their esthetic, physical, and mechanical properties degraded after remaining in the oral cavity. Acrylic resins are prone to sorption, a process of absorption and adsorption of liquids, which depends on environmental conditions. The material stains with time due to its contact with drinks, food and nicotine. Beverages such as tea, coffee, Coke, juices, and wine significantly promote the development of stains in dental materials, and so does nicotine. Keyf and Etikan ${ }^{7}$ assessed the changes on polished and unpolished resins in contact with a wide variety of drinks and observed change in brightness of all samples, with major changes being observed in unpolished surfaces.

Reis et $\mathrm{al}^{13}$ observed that the susceptibility of staining in acrylic resins is not only related to surface roughness, but also to intrinsic factors (staining of the bulk of resin) and extrinsic (adsorption and absorption of pigment of exogenous sources). Low susceptibility to staining is related to low range of water adsorption after finishing and polishing.

Finishing and polishing procedures aim at obtaining a smooth and shiny surface for acrylic resins used to make orthodontic appliances, ${ }^{2}$ thus, facilitating hygiene, preventing staining and providing greater comfort to the patient. The purpose of this study was to analyze the surface morphology ${ }^{19}$ of acrylic resins in each step of mechanical finishing and polishing. 


\section{MATERIAL AND METHODS}

Rings $10 \mathrm{~mm}$ in diameter and $5 \mathrm{~mm}$ in length were made of stainless steel bands. The stainless steel rings were placed over a glass plate isolated with solid vaseline. Self-curing acrylic resin (powder and liquid) (Clássico, Sao Paulo) was manipulated in the proportion described by the manufacturer, poured into the rings where it remained for 20 minutes until polymerization took place. The resin discs were removed from the rings and randomly divided into 10 groups of 3 , totalizing 30 samples.

The upper face of each sample was treated as described below. The control group did not receive any treatment while the Kaol group received the entire finishing and polishing treatment. The other groups were submitted to subsequent steps of finishing and polishing, as stated in Table 1.

The wearing out phase was performed with multilaminated burs, by which $1 \mathrm{~mm}$ of resin was removed. Sanding was performed with up-and-down movements, repeated 100 times, and the direction of sanding was changed in 90 degrees every time a sandpaper was replaced. Wood sandpaper polishing was performed without water, while water paper polishing was performed under refrigeration of a small flood of water. At the end of each step, the samples were cleaned with water to remove any particles of the sandpaper used in the previous phase. Polishing performed with pumice and water was carried out with a woolen wheel for 15 seconds. The discs were cleaned, dried and polished with low abrasive liquids for metal polishing (Kaol) in a woolen disc for 10 seconds. At the end of all steps, the samples were washed with soap and dried with paper.

Table 1 - Treatments performed with each group.

\begin{tabular}{lll}
\hline Group & n & Finishing and polishing phases \\
\hline Control & 3 & No finishing/polishing \\
\hline Burs & 3 & Wearing out with multilaminated burs \\
\hline 150 & 3 & Finishing with wood sandpaper 150 \\
\hline 180 & 3 & Finishing with wood sandpaper 180 \\
\hline 220 & 3 & Finishing with wood sandpaper 220 \\
\hline 400 & 3 & Finishing with water sandpaper 400 \\
\hline 600 & 3 & Finishing with water sandpaper 600 \\
\hline 1200 & 3 & Finishing with water sandpaper 1200 \\
\hline Pumice & 3 & Polishing with pumice + water \\
\hline Kaol & 3 & Polishing with Kaol \\
\hline
\end{tabular}

The superficial roughness of the samples was analyzed under the parameters $\mathrm{Ra}, \mathrm{Rq}$, and $\mathrm{Rz}$ in micrometers $(\mu \mathrm{m})$. This scale translated the value of linear means of all absolute distances of the roughness profile from the central line $(\mathrm{L})$ to the extension of measurement. After that, the samples were metallized and the surface morphology was analyzed through scanning electron microscopy with secondary electrons image.

\section{RESULTS}

The untreated discs of acrylic resin showed surfaces with bubbles (Fig. 1A) which were not observed after the wearing out phase performed with multilaminated burs (Fig 1B). Finishing with wood sandpaper resulted in surfaces with irregularities (Figs 1C, 1D and 1E) which remained the same, but with low thickness, after finishing with water sandpaper (Figs 1F, 1G and $1 \mathrm{H}$ ). The acrylic resin surfaces polished with pumice and water had significantly alterations in their morphology, showing high surface smoothness (Fig 1I). This characteristic was also observed, but in low magnitude, after polishing with low abrasive liquids (Kaol) (Fig 1J).

The alterations in surface roughness were compatible with the quantitative assessment, hence, they significantly decreased during finishing and polishing procedures of acrylic resins (Table 2). The first step of finishing performed with multilaminated burs, resulted in regular deformities, increasing the values of surface roughness. The sequence of sandpapers and the pumice gradually decreased the values of surface roughness. Final polishing performed with low abrasive liquids caused the surface to be even smoother, however, it is considered less effective than the previous steps.

\begin{tabular}{lccc} 
Table 2 - Surface roughness at finishing and polishing phases. & \\
\hline Group & $\mathbf{R a}$ & $\mathbf{R q}$ & $\mathbf{R z}$ \\
\hline Control & $1.25 \mu \mathrm{m}$ & $1.57 \mu \mathrm{m}$ & $7.63 \mu \mathrm{m}$ \\
\hline Burs & $1.52 \mu \mathrm{m}$ & $1.90 \mu \mathrm{m}$ & $8.99 \mu \mathrm{m}$ \\
\hline 150 & $1.33 \mu \mathrm{m}$ & $1.72 \mu \mathrm{m}$ & $8.72 \mu \mathrm{m}$ \\
180 & $1.03 \mu \mathrm{m}$ & $1.32 \mu \mathrm{m}$ & $6.31 \mu \mathrm{m}$ \\
\hline 220 & $0.85 \mu \mathrm{m}$ & $1.44 \mu \mathrm{m}$ & $6.05 \mu \mathrm{m}$ \\
400 & $0.60 \mu \mathrm{m}$ & $0.90 \mu \mathrm{m}$ & $4.10 \mu \mathrm{m}$ \\
\hline 600 & $0.48 \mu \mathrm{m}$ & $0.65 \mu \mathrm{m}$ & $3.12 \mu \mathrm{m}$ \\
1200 & $0.42 \mu \mathrm{m}$ & $0.53 \mu \mathrm{m}$ & $2.81 \mu \mathrm{m}$ \\
\hline Pumice & $0.28 \mu \mathrm{m}$ & $0.36 \mu \mathrm{m}$ & $1.97 \mu \mathrm{m}$ \\
\hline Kaol & $0.25 \mu \mathrm{m}$ & $0.34 \mu \mathrm{m}$ & $1.92 \mu \mathrm{m}$ \\
\hline
\end{tabular}



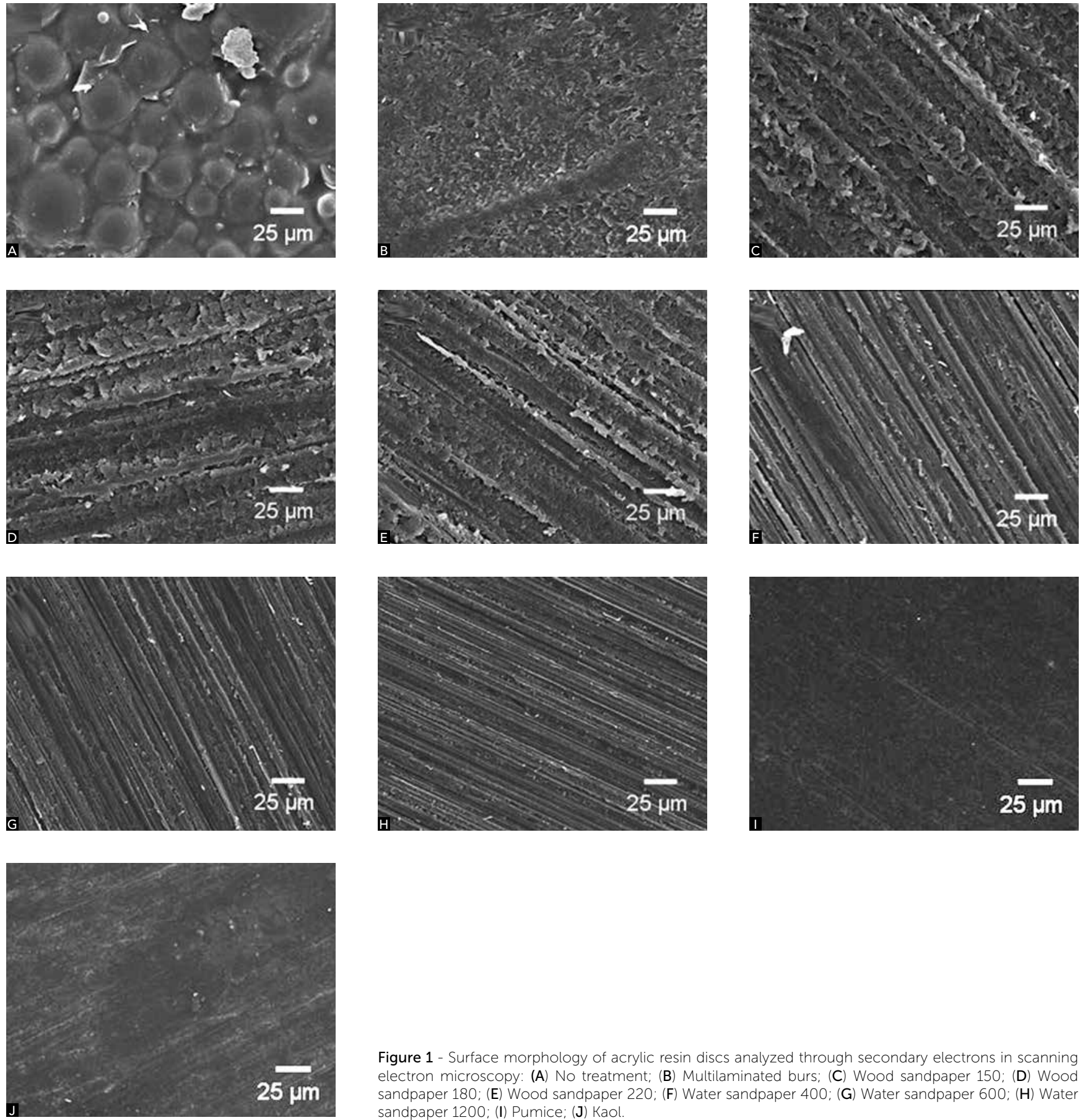

Figure 1 - Surface morphology of acrylic resin discs analyzed through secondary electrons in scanning electron microscopy: (A) No treatment; (B) Multilaminated burs; (C) Wood sandpaper 150; (D) Wood sandpaper 180; (E) Wood sandpaper 220; (F) Water sandpaper 400; (G) Water sandpaper 600; (H) Water sandpaper 1200; (I) Pumice; (J) Kaol.

\section{DISCUSSION}

According to Adams, ${ }^{1}$ the heat-curing and self-curing acrylic resins are used to make removable orthodontic appliances. With the use of self-curing acrylic resins it is possible to easily repair and adjust orthodontic appliances, however, these resins have low staining resistance. On the other hand, making orthodontic appliances with heat-cured acrylic resins in laboratory is complex and time-consuming. ${ }^{9}$ Staining and accumulation of dental plaque are directly related to surface roughness. ${ }^{12,13,16,20}$ Thus, a smooth and polished surface is desirable.

The results of this work showed that finishing and polishing procedures resulted in roughness-free surfaces. These findings corroborate those found by Chung ${ }^{5}$ who analyzed the effects of finishing and polishing on roughness of composite resins and concluded that these procedures decreased surface roughness. The tendency in Orthodontics, as in other areas, is to simplify the 
technical procedures in a way that the aims are achieved with least effort. ${ }^{14}$ However, highly smooth acrylic resins surfaces are obtained after complete mechanical finishing and polishing, only.

Multilaminated burs are used during mechanical polishing to remove excess acrylic, give shape and smooth the surface of the appliance. ${ }^{11}$ After this phase was completed, it could be observed that the surface of the resin showed many irregularities. Finishing starts with wood sandpaper used with the purpose of making the surface as smooth as possible. ${ }^{10}$ In this phase, the acrylic surface is still irregular, with evident grooves. After that, water sandpapers are used, until a uniform surface is seen, without the marks left by the wood sandpaper. ${ }^{10}$ This procedure results in a surface with fewer irregularities than the ones previously seen. The next step is polishing with woolen discs and pumice until a smooth and polished surface is seen, without the marks left by water sandpaper. ${ }^{10}$ The analysis of surface roughness associated with scanning electron microscopy met the aims after these steps were carried out. At last, final polishing is performed with woolen discs and low abrasive liquids. ${ }^{10}$
After that last step, the morphology of the acrylic surface caused surface smoothness to increase.

It is worth noting that the methods of analysis through scanning electron microscopy and laser profilometer give useful information about the morphology and roughness of the samples surfaces in a micrometrical scale. For further investigations carried out in smaller scales, other tools such as atomic force microscopy, must be used. ${ }^{17}$

\section{FINAL CONSIDERATIONS}

Before an orthodontic appliance is placed into the mouth, it should be highly polished. The rough surface of the orthodontic appliance makes it uncomfortable, promotes dental plaque accumulation and biofilm formation, thus, reducing resin shining. Furthermore, smooth and polished surfaces are less prone to bacterial colonization, therefore, they are more desirable.

Highly smooth acrylic resin surfaces are obtained after mechanical finishing and polishing performed with burs, wood sandpapers, water sandpapers, pumice, and low abrasive liquids (Kaol).
1. Adams CP. Aparelhos ortodônticos removíveis: desenho, uso e aplicação. 1a ed. São Paulo: Ed. Santos; 1987.

2. Anusavice KJ. Phillips - Materiais dentários. 11a ed. Rio de Janeiro: Elsevier; 2005

3. Bacetti T, Franchi L, McNamara JA. Treatment and posttreatment craniofacial changes after rapid maxillary expansion and facemask therapy. Am J Orthod Dentofacial Orthop. 2000;118(4):404-13.

4. Chung $\mathrm{CH}$, Font B. Skeletal and dental changes in the sagittal, vertical, and transverse dimensions after rapid palatal expansion. Am J Orthod Dentofacial Orthop. 2004:126(5):569-75

5. Chung $\mathrm{KH}$. Effects of finishing and polishing procedures on the surface texture of resin composites. Dent Mater. 1994;10(5):325-30.

6. Graber TM, Vanarsdall RL. Orthodontics current principles and techniques. 3rd ed. St. Louis: Mosby; 2000.

7. Keyf F, Etikan I. Evaluation of gloss changes of two denture acrylic resin materials in four different beverages. Dent Mater. 2004;20(3):244-51.

8. Machado C, Barbosa C, Gabriotti M, Joia F, Ribeiro M, Sousa R. Influence of mechanical and chemical polishing in the solubility of acrylic resins polymerized by microwave irradiation and conventional water bath. Dent Mater. 2004;20(6):565-9.

9. Moyers RE. Ortodontia. 4a ed. Rio de Janeiro: Guanabara Koogan; 1991.

10. Mucha JN. Grampos e placas ortodônticas: introdução à técnica básica de laboratório. Rio de Janeiro: Ed. Guanabara Koogan; 1997.

11. Orsi IA, Andrade VG. Effect of chemical disinfectants on the transverse strength of heat-polymerized acrylic resins submitted to mechanical and chemical polishing. J Prosthet Dent. 2004:92(4):382-8.
12. Radford DR, Sweet SP, Challacombe SJ, Walter JD. Adherence of Candida albicans to denture-base materials with different surface finishes. J Dent. 1998;26(7):577-83.

13. Reis AF, Giannini M, Lovadino JR, Ambrosano GM. Effects of various finishing systems on the surface roughness and staining susceptibility of packable composite resins. Dent Mater. 2003:19(1):12-8.

14. Retief DH, Denys FR. Finishing of enamel surfaces after debonding of orthodontic attachments. Angle Orthod. 1979;49(1):1-10.

15. Richard VN. Introdução aos materiais dentários. 2a ed. Porto Alegre: Elsevier; 2004

16. Rosan B, Lamont R. Dental plaque formation. Mic Infect. 2000:2:1599-1607.

17. Seitavuopio P, Rantanen J, Yliruusi J. Tablet surface characterisation by various imaging techniques. Int J Pharm. 2003 Mar 26;254(2):281-6.

18. Taner T, Haydar B, Kavuklu I, Korkmaz A. Shot-term effects of fiberotomy on relapse of anterior crowding. Am J Orthod Dentofacial Orthop. 2000;118(6):617-23.

19. Kaplan BA, Goldstein GR, Vijayaraghavan TV, Nelson IK. The effect of three polishing systems on the surface roughness of four hybrid composites: a profilometric and scanning electron microscopy study. J Prosthet Dent. 1996;76(1):34-8.

20. Wrigth PS. Soft Lining materials: their status and prospects. J Dent. $1976 ; 4(6): 247-56$ 